\title{
E-Business, SMEs and Risks: Towards a Research Agenda
}

\author{
Dr. Arun Sukumar (Corresponding Author) \\ Department of Management \\ Glasgow Caledonain University, United Kingdom \\ a.sukunar@gcal.ac.uk \\ Prof. David Edgar \\ Division of Management \\ Glasgow Caledonain University, United Kingdom \\ d.a.edgar@gcal.ac.uk
}

\begin{abstract}
Electronic business is a phenomenon that is becoming more widely researched and better understood. However, an extensive literature review has reviled limited understanding of the nature of e-business risk in organisations, and in particular in small to medium size organisations (SMEs). This paper explores the perceptions of five different stakeholder group respondents from across a range of SME organisations and members of e-business clubs. The results are intended to set an agenda for research into e-business risk and highlight that key themes revolve around strategic risk, customer risk, branding risk, security threats, legal and tax risks, leadership risks, outsourcing and dependency risk and technology risk. These themes are modelled to highlight theme dependencies and to assist in setting the research agenda.
\end{abstract}

Keywords: Management of small business and enterprise, risk management, e-business 


\section{Introduction}

Electronic business is a phenomenon that is becoming more widely researched and better understood. The area is reasonably well defined and has started to emerge as a field of study, both as part of business courses and as specific programmes. In parallel, businesses are increasingly embedding technology into their business processes and seeking to exploit the efficiency and effectiveness gains that can occur from the use of "e-business" either in its entirety or in specific organisational functions or processes. Such industry and academic interest has spawned a range of research interests and resulted in both normative and formative proposals of how e-business can be used, developed and exploited. In searching the range of research papers, we were surprised to find a lack of research into the risks associated with e-business and in particular e-business practices in small to medium size organisations (SMEs). As such, we identified the need to undertake research into perceptions of e-business risk and to seek to set a research agenda into the field that will make a meaningful contribution to both academia and industry. This paper presents the finding of the initial study and in effect sets the research agenda for the future. The paper is structured around five key areas, the literature review, research context, methodology, findings and discussion, and conclusions and implications.

\section{Literature Review}

Electronic business ${ }^{\mathrm{i}}$ or 'E-Business' the term coined by IBM $^{\mathrm{ii}}$, has deeply affected the working aspects of many modern day businesses. According to Krishnan (2003) the impact of E-Business is felt in every industry, with research (Safran and Franklin, 2002) suggesting that purchases of goods and services over the Internet is expected to increase by 60 percent annually to 3.5 trillion by 2006. Typically, by 2010, online retail sales alone are expected to reach $\$ 329$ billion, thus representing a compounded growth of 14 percent from $\$ 174.2$ billion in 2005. In the United Kingdom (UK), according to a recent report published by Internet Media in Retail Group (IMRG) (2005), £42 billion worth of goods have been bought online by British shoppers since 2000 and by 2010 online shopping is expected to expand a further by 320 percent approaching $£ 60$ billion per annum and representing 20 percent of all retail sales. Research by Hammond (2001) also predicts that by 2006, several business categories can expect at least 10 percent of their sector sales from Internet transactions.

The familiarity and depth of E-Business adoption has mainly been attributed to the perceived benefits attained by usage of Internet and related technologies (Tapscott, 1998). Specifically it has been observed that large companies with their resources have been quick to adopt E-Business initiatives and have been successful in developing new and innovative business models (Daniel \& Grimshaw, 2002). According to a recent survey conducted by e-Business W@tch (2006), 76 percent of large corporations in Europe use Intranet to link corporate operations and nearly 88 percent of them use advance technologies to fulfil their business objectives. 
Also, in a report published by the Office of National Statistics (2004), it has been observed that more than 50 percent of large businesses (> 250 employees) have integrated electronic processes that are linked externally or internally with other electronic systems for placing or receiving orders. The report also notes that for the year 2005, £49.8 billion was generated from sales over the Internet by large businesses representing an increase of 35.5 percent compared to the previous year.

The popularity of E-Business has not only been felt in large firms, but also in small and medium sized enterprises (SME) ${ }^{\text {iii }}$. In the United Kingdom (UK) the extent of SMEs contribution to the economy through the use of E-Business initiatives can be extracted from the annual survey conducted by Office of National Statistics (ONS). The latest survey (2005) notes that, with regards to the use of Internet to sell products and services, UK businesses accounted for nearly $£ 103.3$ billion through Internet sales in 2005; this represents an increase of 56 percent compared to the previous year's figure of $£ 66.2$ billion. SMEs in 2005 have contributed to nearly $£ 25.2$ billion in Internet sales, an increase of 113 percent compared to the previous year figure of 11.8 billion. Similarly, while considering the use of the Internet for purchasing, it has been noted that UK businesses bought about $£ 72.8$ billion worth of products and services through the Internet in 2005, representing an increase of 50 percent compared to the previous year’s figure of $£ 48.4$ billion. SMEs have outmatched their larger counterparts (between 250-1000 employees) in utilising the Internet for online purchases. SMEs, in 2005 contributed to nearly 40 percent (£28.8 billion) of total online purchases, an increase of 15 percent (£18.7 billion) over larger firms (250-1000 employees).

The extent of Internet as well as non-Internet based ICT adoption among SMEs can also be gauged from the ONS (2005) survey. In relation to the adoption of Internet, it has been reported that over 65 percent of small businesses and 86 percent of medium sized business have their own web sites, while nearly 90 percent of all small and medium sized businesses utilise workstations, personal computers (PCs) or terminals to run their businesses. In relation to the degree of technology adoption, in 2005, 37.5 percent of medium sized businesses (50-249 employees) have reported the use of electronic systems to link business processes and 18.5 percent of small businesses (10-49 employees) have had a Wireless Local Area Network (WLAN) set-up.

Similar to popularity, E-Business has also benefited from studies with varying research foci. For example, from a broader contextual base, the area of E-Business marketing has gained considerable exposure through the works of Mahajan and Venkatesh (2000), Shankar et al (1999), Zettlemeyer (2000), Hoffman and Novak (2000) while online supply chain management has benefited from studies conducted by Johnson and Wang (2003), Lee and Wang (2001) and Poirier (1999). Similarly, in relation to strategic adoption and business models, it has been noted that E-business has been researched through the works of Wu et al (2003), Srinivasan et al (2002), and Kalakotta and Robinson (2001). A list of extensive 
research done in E-Business is given in table 1.

While there is abundance of research in E-Business, there is a lack of research focusing at unearthing the risk issues at an SME level emanating from the usage of E-business technologies. Research into E-Business in an SME context has concentrated on many different themes (for a full list of studies, see Daniel et al (2002, p. 255) but a study towards risk issues is largely absent. This research paper primarily focuses on addressing the lack of knowledge in this area and will highlight the risk issues that are pertinent to SMEs. SMEs are different from their larger counterparts and have a different risk profile (Clink, 2001) and E-Business risk studies aimed at larger organisations have not sufficiently portrayed the true extent of threats faced by SMEs. There is a need to study E-Business risks in their own context and identify issues that are pertinent to their environment. Hence, the overall aim of this paper is to contribute to the understanding of E-business risk issues in Small and Medium Sized Enterprises (SMEs) in United Kingdom (UK) and set the tone for further research in this area.

Table 1. Studies relating to E-Business

\begin{tabular}{|c|c|}
\hline Area of Study & Author \\
\hline Supply Chain Management & $\begin{array}{l}\text { Harland et al (2003); Lancioni et al } \\
\text { (2000); Lancioni et al (2002); Prestige } \\
\text { (2003). }\end{array}$ \\
\hline $\begin{array}{lll}\text { Customer } & \text { Relationship and } \text { Online } \\
\text { Marketing } & & \end{array}$ & $\begin{array}{l}\text { Wilson (2002); Schoder and Yin (2000); } \\
\text { Ribbink et al (2004); Ratnasingham } \\
\text { (1998); Kotha et al (2001), Koehn } \\
\text { (2003); Rotondaro (2002); Kartalia } \\
\text { (2000); Jones et al (2000); Jarvenpaa and } \\
\text { Tiller (1999); Jarvenpaa et al (2000); } \\
\text { Janda et al (2000); Hoffman et al } \\
\text { (1999); Harridge (2004), Grabner-Krauter } \\
\text { and Kaluscha (2003), Friedman et al } \\
\text { (2000); Daughtrey (2001); Corritore et al } \\
\text { (2003); Corner and Hinton (2002). }\end{array}$ \\
\hline Strategy & $\begin{array}{l}\text { Kambil (1995); Willcocks and Plant } \\
\text { (2001); Tapscott (1998); Shapiro and } \\
\text { Varian (1999), Rayport, and Jaworski } \\
\text { (2001), Plummer (1999); Morath (2000); } \\
\text { Kalakota and Robinson (2001); Cote et al } \\
\text { (2005); Hoffman and Novak (2000); } \\
\text { Porter (2001); Venkatraman (2000); } \\
\text { Eisenhardt (1999). }\end{array}$ \\
\hline
\end{tabular}




\begin{tabular}{|c|c|}
\hline E- Business Model Analysis & $\begin{array}{l}\text { Krell and Gale (2005); Barua et al, } \\
\text { (2001); Kaplan and Sawhney (2000); } \\
\text { Rayport (1999); Wise and Morrison } \\
\text { (2000); Mahadevan (2000); Evans and } \\
\text { Wurster (1999); Dutta and Segev (1999); } \\
\text { Timmers (2000); Willcocks and Plant } \\
\text { (2001). }\end{array}$ \\
\hline Online Branding & 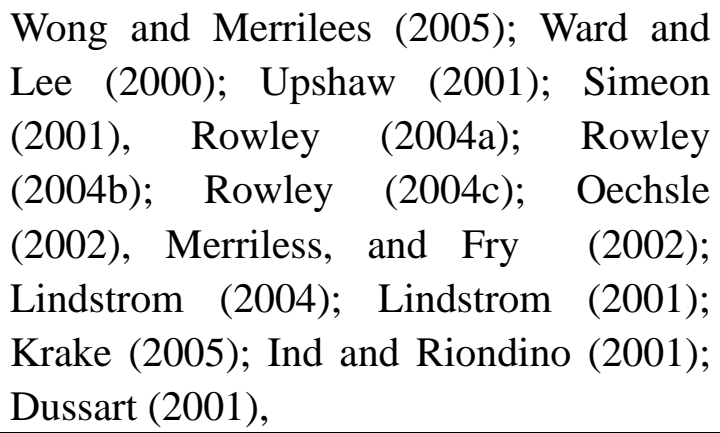 \\
\hline Economics of E-Business & $\begin{array}{l}\text { Love et al (2005); Love et al (2004); } \\
\text { Kleist (2003); Grey et al (2003); } \\
\text { Figueiredo (2000), }\end{array}$ \\
\hline Organisational Change and E-Business & $\begin{array}{l}\text { Earl and Khan (2001); Dutta and Segev } \\
\text { (1999), Eisenhardt (1999). }\end{array}$ \\
\hline Managing Internet Technologies & $\begin{array}{l}\text { Day and Shoemaker (2000); Luftman } \\
\text { and Brier (1999), Chan (2001) }\end{array}$ \\
\hline
\end{tabular}

Adapted from Drew (2002, p.22)

\section{Research Context}

Some firms see the potential shortening of the supply chain as a great opportunity to make more profits (Poirier \& Bauer, 2001). Others use the E-Business medium to create a level of customisation that the industries have probably never seen before (Wilson, 2002). While there are many advantages in the use of E-Business initiatives (Kalkotta \& Robinson, 2001; Nasser, 2001; Soliman \& Youssef, 2001; Plummer, 1999) there are also risks, which arise due to the deployment of such initiatives. According to Beck et al (2002), the online environment is in a constant state of flux; its dynamism and constant change has resulted in the emergence of risks that are difficult to measure and respond.

With its new business models and practices E-business has significantly contributed to the change in corporate risk profile (Pederson, 2002). Moscove (2001) points out that business risks for a company engaged in E-business are normally greater than from their traditional counterparts and by commencing E-Business operations, organisations are presented with risks that are unique, dynamic and fast-evolving. In a similar note Pennathur (2001) further adds that for organisations adopting E-Business initiatives, traditional risks are magnified and 
new risks arise that are both challenging and unpredictable.

Studies on E-Business risks have mainly concentrated on the information security issues arising from working through the online medium. Authors like Ghosh, (1998, 2001), Hassler (2001) and Garfinkel and Spafford (2002) have given insights into mechanism of online transactions and their relevant security lapses, while works by Solms (1999) (2003), Moscove (2001), Wen (1998), Greenstein and Vasarhelyi (2002), Hubbard and Forscht (1998) have highlighted the severity and impact of inadequate security controls. Apart from these extensive investigations in security related areas, research has also addressed other aspects of E-Business risks. For example, the legal aspects of conducting online business are characterised by Poindexter and Baumer (2002) and Oppenheim (1999). Smith (2000) has characterised the risks arising out of improper strategy thought and its implementation. Chan et al (2000) have dealt with issues of online trust and relationship while Rossi (2002) has given an overall view on the nature of the risks from an Insurance point of view.

While these studies have focused on different aspects of E-Business risks, there are also other studies that have gone further in developing a classification framework for E-Business risks. Specifically, Beck et al (2002) in their study of E-Business risks have classified E-business risks along the traditional lines of strategy, operational, legal and financial domains. Their analysis is based on the nature of the risks to which an E-business initiative is exposed. Namely, the non E-specific risks, the E-specific risks and lastly the non-E-Specific risks resulting from increased E-commerce significance. E-Specific risks relate to the threats that arise specifically and uniquely from the context of E-Business initiatives, prime examples include technology risks like viruses, systems failure and dependency on outside agencies for system development and maintenance. Non-Specific E-Business risks are threats that require strategic revaluation in the context of an E-Business venture. Examples include threats like branding and reputation, which are emergent and require strategic valuation because of the decision of the company to engage in E-Business operations. Threats like intellectual property violations denote the last of the classification, E-Business risks with increased significance. These risks though not unique to the E-Business environment but have gained importance due to the variations offered by the use of Internet and allied technologies. A full list of risks explored by Beck et al (2002) is shown in Table 2

Table 2: Beck et al's (2002) classification of E-Business risks

\begin{tabular}{|l|l|l|}
\hline Risk Category & E-Specific & Increased Significance \\
\hline Strategic Direction & No & Possible \\
\hline $\begin{array}{l}\text { Outsourcing } \\
\text { Dependency }\end{array}$ & Primarily & Possible \\
\hline
\end{tabular}




\begin{tabular}{|c|c|c|}
\hline Brand & No & Possible \\
\hline Customer Expectations & No & Likely \\
\hline Reputation & No & Possible \\
\hline Governance & No & Likely \\
\hline Cultural & No & Possible \\
\hline Employee Malfeasance & Partially & Likely \\
\hline Skilling/Staffing & Partially & Possible \\
\hline Technology & Yes & Possible \\
\hline Security & Yes & Yes \\
\hline Business Process & Partially & Possible \\
\hline Operations & Yes & Possible \\
\hline Legal/ Regulatory & Partially & Likely \\
\hline Financial & No & Unlikely \\
\hline
\end{tabular}

Source: Beck et al (2002, p, 12)

Similar to Beck et al's (2002) classification of E-Business risks, Scott (2004) has developed a classification scheme for E-business risks. The classification framework is developed along the dimensions of policy, strategy and operations. In developing the classification framework, Scott (2004) has identified sixteen different E-Business risks and has grouped them along the areas of policy, strategy and operations based on empirical evidence. Main threats like security, intellectual property violations and privacy come under the scope of policy risks while threats related to leadership, reputation, culture, legal issues were grouped under organisational risks. Strategic risks are those that are of concern to higher management and include competition, dependency on vendors and developing suitable and sustainable strategies to deal with the dynamic E-Business environment. The classification framework developed by Scott (2004) is shown in table 3. 
Table 3: Scott’s (2004) Classification of E-Business risks

\begin{tabular}{|l|l|l|}
\hline Strategy risks & Organisational risks & Policy risks \\
\hline Strategy & Reputation & Security \\
\hline Competitive & Reliability & Privacy \\
\hline Dependency & Leadership & Identity \\
\hline & Culture & Intellectual Property \\
\hline & Expertise & \\
\hline & Currency & \\
\hline & Legal & \\
\hline
\end{tabular}

Source: Scott (2004, p. 47)

Apart from these classification frameworks, there have also been number of other works focussed at classifying E-Business risks, which have not been empirically verified. For example Krishnan (2003) has categorised E-business risks on dimensions of strategy, operations and security while Upton (2001) bases his classification model on internal and external sources of risks that are applicable to an organisation. These works though exploratory in nature are devoid of empirical data to verify the classifications outlined.

The above-mentioned studies on E-Business have been developed with the empirical studies carried out with large organisations (> 250 employees). In the case of Beck et al (2002), the studies were carried out with UK based insurance companies to ascertain the scope and nature of E-Business risks, while in the research conducted by Scott (2004), data was collected from US companies and the risks were modelled on the socio-technical environment of the prevailing society. Studies' focussing at E-Business risks at an SME level is largely absent. This research mainly addresses this absence/lack of study in this field. Its purpose is therefore is to

1) To investigate the E-business risks associated with SMEs

2) To set a research agenda for further exploration in this area 


\section{Research Methodology}

The first step in addressing the E-Business risks of UK SMEs is to develop a rich picture of the range threats are pertinent to their environment. Two related approaches were used to develop the risk issues. Firstly, an extensive literature review was conducted to identify the risk issues and secondly, in-depth interviews were conduced with SME stakeholders to develop and refine the identified E-Business risk themes. In the literature review, search was especially made at identifying the classification frameworks/models that were used to study E-Business risks and an effort was made at integrating these frameworks to identify the risk issues that were more significant to SMEs. The results of the literature review were then used as a basis for conducting in-depth interviews. The interviews were conducted with SME stakeholders with different perspectives. Accordingly, Interviewees with experience in E-Business were chosen from Academic, Public sector, Policy, Forum and Private sector to obtain their views on E-Business risks and to develop a rich picture on the same. A total of fifteen interviews were conducted and the data from the interviews were coded with the help of coding software NVivo. The data was then analysed and developed into themes to derive a model of E-Business risks.

\section{Results and Discussion}

The results from the literature review and the Interviews revealed several inter-related E-Business risk issues that are relevant to SMEs. The list of the issues identified is stated in table 4.

Table 4: Themes of e-business risk

1. Security threats

a. External security threats

b. Internal security threats

2. Reputation, Branding and customer related risks

3. Legal Risks and Tax

4. Outsourcing and Dependency risks

5. Leadership, cultural and expertise risks 
6. Technology risks

7. Risks Strategic risks

Discussing each of the risk issues.

\subsection{Security Issues}

The first and the foremost risk issues was that of online security. SMEs were subjected to variety of online threats including credit card fraud, identity thefts, email misuse and attacks by viruses, worms and hackers. Fraudulent Internet and network access and transactional risks were also quoted as important threats affecting E-Business organisations. Also with the advent of wireless technologies, interviewees were also of the opinion that, transactional data can be intercepted and used illegally by hacker and criminal elements. On the subject of support received from the government agencies in tackling on line crimes. SME entrepreneurs had difficulties in obtaining official support and were far from satisfied by the support shown by acting agencies.

\subsection{Reputation, Branding and Customer related threats}

In relation to customer related risks, SMEs pointed out that consumer trust was one of the major factors affecting their online businesses. Measures of trust namely, online reviews, rating, seals of approval have all been employed and have played an important role in gaining online trust. They also have helped in boosting consumer confidence and reputation of their businesses. But again owing to their size and amount of transaction involved they are finding it difficult to develop online trust. Invariably security has also played an important role in enticing customers for online trading. Stakeholders feel that any lapses in online security will ultimately affect the reputation and online confidence of customers. Because of their resource constraints SMEs also state that it may be difficult for them to regain their online reputation after any security related incident.

\subsection{Legal and taxation risks}

In relation to the online legal risks, SMEs have are apprehensive of the current legal laws. They are aware of intellectual property rights violations (copyright, trademark, linking, framing etc) but their lack of further knowledge and support has not helped them to be proactive in safeguarding their intellectual properties. Lack of knowledge and absence of a facilitator who can guide the SMEs in legal matters were cited as the two of the most important threat issues that require attention. Again, a mention is made on the lack of financial resources of SMEs in obtaining legal support to safeguard their online intellectual properties. In relation to online taxing SMEs are comfortable with the current taxing regimes 
and procedures. Transactions outside EU, is one of the areas whether there is a slight concern relating to applicability of tax laws. But the information provided by HMRC has made it easier for them to carry transactions outside EU.

\subsection{Outsourcing and Dependency Risks}

SMEs are mainly apprehensive on the dependency on contractors and web developers to run their business. They are doubtful on the intentions of contractors and are unaware of the security and intellectual property issues related with the employment of outside vendors and contractors to build and run their applications and computer systems. They are dependent on outside sources to run their business and the absence of ratings or scale in gauging the worth of the contractors/ content developers is one of the main hindrances in selecting suitable partners. In relation to suppliers, again as with contractors, SMEs are dependent upon outsourcing partners to run their business. The success of the business is largely dependent on the relationship developed with the suppliers and is major factor in smooth running of the operations.

\subsection{Staff and Leadership Risks}

SMEs are also critical about the lack of leadership figures and board support within their organisations to identify and run E-Business projects. Lack of knowledge of E-Business and an understanding of the technical and non-technical issues have been quoted as the main obstacles in developing online businesses.

Regarding, the role-played by internal staff in contributing to E-Business risks, the interviewees of the opinion that lack of knowledge among the staff and resistance to change as one of the main obstacles in the success of E-Business operations. Particularly disgruntled employees inflict deliberate damages to computer systems and sometimes hold businesses at ransom for fulfilment of their objectives. Accidental damages to systems either unknowingly or by not following proper polices, procedures have also contributed to the risk profile emanating from staff working with the company.

\subsection{Technology Risks}

Risks relating to technology were mainly attributed to the computer systems failure- both hardware and software failures were mentioned as significant threats. Rapid change of technology and the problem of legacy systems were highlighted as one of the key threats that could undermine the success of E-Business operations. SMEs entrepreneurs were particularly concerned about the lack of technological support they could draw upon to treat system related problems. They are dependent on partners or contractors for system support and are apprehensive on the dependency of external partners to run mission critical systems. 


\subsection{Strategic Risks}

With regards to strategic risks, one of the main emanating issues was the lack of availability of suitable valuation models to gauge the worth of E-Business investments. SME entrepreneurs stated the need for verified valuation models to evaluate the cost/benefit of their technological investments. SMEs entrepreneurs also cite lack of knowledge on E-Business as a main barrier in taking informed decisions. Particularly, when it comes to competition and linking profits to investments, SMEs note that they lack the necessary tools to develop a good picture of their E-Business projects. They also cite the lack of understanding of the E-Business risk issues as a fundamental deficiency in tackling online ventures.

\subsection{Ranking of the risks}

Upon being asked to rank the E-Business risks, Security related issues were rated as the most severe, especially threats from credit card fraudsters and illegal data access were cited as the most important risks. Next to online security, the interviewees noted lack of good leadership, lack of knowledge and the risks emanating from internal staff as second most important E-Business risk area. Customer related threats were rated third in the list with outsourcing and dependency risks following them. Legal risk issues were rated on the other end of the scale with tax being rated as the least severe risk area.

\subsection{Modelling the risk themes}

The different risks themes modeled as follows 


\section{Macrothink}



\section{Conclusions and Implications}

The paper set out at investigating the E-Business risk issues of SMEs, the literature review was able to list several risk themes which were further refined by the interviews. Within the risk profile, security threats and surprisingly leadership risks were rated highly among SME stakeholders. They are apprehensive of the security- related threats and cite their lack of knowledge in that area as an impediment to delve deeper into E-Business adoptions. Problems with internal staff, their lack of knowledge and sometimes deliberate damage to systems have all contributed to the SME risk profile. Among the least concerns were the tax issues of conducting business online. SMEs were supported by the clear guidelines from HMRC on overseas and VAT transactions. Among the areas of concern was the lack of knowledge on E-Business risk issues. This lack of knowledge can only be addressed by carrying out empirical research in this area. Though security related threats have taken the mantle of the most important E-Business risk, this study has examined a comprehensive list of other risk issues and has built awareness on the same. It has laid the foundations for better understanding of E-Business risk issues and has contributed to knowledge in this area.

With the rapid growth of E-Business initiatives among UK SMEs, it is imperative research is 
focussed on studying the risk issues that have the potential to impact the existence of SMEs. Research is important because of the severe consequences of neglecting risks. This paper is an initial step towards research in this area and more detailed research can not only enhance our knowledge of the risk issues but can act as a platform for further study. Future research in this area can focus on implementing the developed model and can also strive at devising a measuring instrument that can aid the SMEs in scaling their E-business risks.

\section{References}

Alter, S., (2002) in Alter, S., Scott, J., Dor, P.E., Markus, L., and Vessey, I., Does the trend toward E-Business call for changes in the fundamental concepts of Information systems? A Debate, Communications of the Association for Information Systems, Vol. 5 (10), 2001, pp: 2-58.

Baura, A., Konana, P., Whinston, A.B., and Yin, F., (2001), Driving E-Business Excellence, Sloan Management Review, Vol. 43 (1), pp: 36-45.

Beck, M., Drennan, L., and Higgins, A., (2002), Managing E-Risk. London: Association of British Insurers. pp. 7

Chan, S., Keen, P., Balance, C., and Schrump, S., (2000), Electronic Commerce Relationships: Trust by design, New Jersey: Prentice Hall.

Chan, S., (2001), Risky e-business, The Internal Auditor, Vol. 58 (6), pp: 62-65.

Clink, S., (2001), Risk Management in Small Business, Glasgow: Glasgow Caledonian University PhD Thesis.

Corner, I., and Hinton, M., (2002), Customer relationship management systems: implementation risks and relationship dynamics, Qualitative marker research: An International Journal, Vol. 5 (4), pp: 239-251.

Corritore, C. L., Kracher, B., and Widenbeck, S., (2003), Online Trusts: concepts, evolving, a model, International Journal of Human-Computer Studies, Vol. 58 (6), pp: 737-758.

Cote, L., Vezina, Mi., and Sabourin, V., (2005), The strategic management process in e-business, Ivey business Journal Online, May/June, pp: 1

Daniel, E., Wilson, H., and Myers, A., (2002), Adoption of E-Commerce by SMEs in the UK: Towards a Stage Model, International Small Business Journal, Vol. 20 (3), pp: 253-270.

Daniel, E., and Grimshaw, D.J., (2002), An exploratory comparison of electronic commerce adoption in large and small enterprises, Journal of Information Technology, Vol. 17 (-), pp: $133-147$.

Daughtrey, T., (2001), Costs of trust for e-business, Quality progress, pp: 38-43.

Day, G.S., and Shoemaker, P.J.H., (2000), Avoiding the pitfalls of Emerging Technologies, California Management Review, Vol. 42 (2), pp: 8-33.

Drew, S., (2002) E-Business Research Practice: Towards an Agenda, Journal of Business research methods, Vol. 1(1), pp. 18-26.

Dussart, C., (2001), Transformative Power of e-business over Consumer Brands, European Management Journal, Vol. 19 (6), pp: 629:637.

Dutta. S., Segev, A., (1999), Business transformation on the Internet, European Management Journal, Vol. 17 (5), pp: 466-76. 
E-Business W@tch (2006), The European E-Business Report, [online], Bonn: e-Business W@tch.

http://www.ebusiness-watch.org/resources/documents/EBR06.pdf [Accessed 4th December 2006]

Earl, M., and Khan, B., (2001), E-Commerce is changing the face of IT, MIT Sloan Management Review, Vol. 43 (1), pp. 64-72.

Eisenhardt, K.M., (1999), Patching: Restitching Business Portfolios in Dynamic Markets, Harvard Business Review, Vol. 77 (3), pp: 72-83.

Evans, P., and Wurster, T.S., (1999), Getting Real about Virtual Commerce, Harvard Business Review, Vol. 77 (6), pp: 84-95

Figueiredo, J M., (2000), Finding sustainable profitability in electronic commerce, Sloan Management Review, Vol. 41 (4) pp: 41-52.

Friedman, B., Kahn, P.H., and Howe, D.C., (2000), Trust Online, Communications of the ACM, Vol. 43 (12), pp: 34-40.

Garfinkel, S., and Spafford, G., (2002), Web Security, Privacy and Commerce, Second Edition, Cambridge: O’Reilly.

Grabner-Krauter, S., and Kaluscha, E.A., (2003), Empirical research in on-line trust: a review and critical assessment, International Journal of Human-Computer Studies, Vol. 58 (-), pp: 783-812.

Grey, W., Katricioglu, K., Bagchi, S., and Shi, D., (2003), An Analytic approach for quantifying the value of e-business initiatives, IBM Systems Journal, Vol. 42 (3), pp: 484.

Greenstein, M. and Vasarhelyi, M., (2002), Electronic Commerce, Security, Risk

Management and, Control, New York: McGraw- Hill Irwin.

Ghosh, K, A., (1998), E-Commerce Security, Weak Links, Best Defences, New York: John Wiley \& Sons.

Ghosh, K, A., (2001), E-Commerce Security and Privacy, Massachusetts: Kluwer Academic Publishing.

Hammond, K., (2001), B2C e-Commerce 2000-2010: What Experts Predict, Business Strategy Review, Vol. 12(1), pp: 43-50.

Harland, C., Powell, P., Caldwell, N., Zheng, J., Woerndl, M., and Xu, S., Supply Network Risks arising from E-Business: Findings from Empirical Research in the Proceedings of the $36^{\text {th }}$ Hawaii International Conference on System Sciences, 2003

Harridge, S., (2004), Electronic Marketing, the new kid on the block, Marketing intelligence and planning, Vol. 22(3) pp: 297-309.

Hassler, V., (2001), Security Fundamentals for E-Commerce, London: Artech House.

Hoffman, D.L., Novak, T.P., and Peralta, M., (1999), Building Consumer Trust Online, Communications of the ACM, Vol. 42 (4), pp: 80-85.

Hoffman, D.L., and Novak, T.P., (2000), How to acquire customers on the web, Harvard Business Review, Vol. 78 (3), pp: 179-188.

Hubbard, J.C., and Forcht, K.A., (1998) Computer viruses: how companies can protect their systems, Industrial Management \& Data Systems, Vol. 98 (1), pp. 12-16.

IMRG (2005), Internet Shopping rockets 30\% in April and marks the end of rip-off Britain. [online], London: IMRG. Available from: 
http://www.imrg.org/ItemDetail.aspx?clg=InfoItems\&cid=pr\&pid=pr_imrg_may05\&la nguage $=$ en $\quad$ [Accessed $2^{\text {nd }}$ July 2006]

Ind, N., and Riondino, M.C., (2001), Branding on the web: A real revolution, The Journal of Brand Management, Vol. 9 (1), pp: 8-20.

Janda, S., Trocchia, P .J., and Gwinner, K. P., (2002), Consumer perceptions of internet retail service quality, International Journal of Service industry Management, Vol. 13(5), pp: 412-431.

Jarvenpaa, S.L., and Tiller, E.H., (1999) Integrated Market, Technology, and policy opportunities in e-business strategy, Journal of Information Systems, Vol.8 (-), pp: 235-249.

Jarvenpaa, S.L., Tractinsky, N., and Vitale, M., (2000), Consumer Trust in an Internet Store, Information Technology and Management Journal, Vol. 1 (-), pp: 45-71.

Johnson, M.E., and Wang, S., (2003), E-Business and Supply Chain Management: An overview and framework, Productions and Operations Management, Vol. 11 (4), pp: 413-423.

Jones, S., Wilikens, M., Morris, P., and Masera, M., (2000), Trust requirements in E-business, Communications of the ACM, Vol. 43(12), pp: 81-87.

Kalakota, R., and Robinson, M., (2001), E-Business 2.0, Road map for Success. Second Edition, New York: Addison- Wesley.

Kambil, A., (1995), Electronic Commerce: Implications of the Internet for Business Practice and Strategy, Business Economics, Vol. 30 (4), pp: 27.

Kaplan, S., and Sawhney, M., (2000), Ehubs: The new B2B Marketplaces, Harvard Business Review, Vol. 78 (3), pp: 97-100.

Kartalia, J., (2000), Reputation at risk?, Risk Management, Vol. 47 (7), pp: 51-58.

Kleist, V.F., (2003), An approach to evaluating E-Business Information System Projects, Information Systems Frontiers, Vol. 5 (3), pp: 249- 263

Krake, F.B.G.F.M., (2005) Successful brand management in SMEs: a new theory and practices hints, Journal of product and Brand Management, Vol. 14 (4), pp: 228-238.

Krell, T., and Gale, J., (2005), E-business migration: a process model, Journal of Organizational Change Management, Vol. 18(2), pp: 117-131.

Koehn, D., (2003), The nature of Trust and Conditions for Online Trust, Journal of Business Ethics, Vol. 43 (-), pp: 3-19.

Kotha, S., Rajagopal, S., Rindova, V., (2001), Reputation building and Performance: An Empirical Analysis of the Top-50 Pure Internet Firms, European Management Journal, Vol. 19 (6), pp. 571-586.

Krishnan, N., (2003) E-Business in the New Economy [online]. Seattle: The Boeing Company. Available from: http://www.swe-pnw.org/ebusiness.pdf. [Accessed 1st October 2005]

Lancioni, R, Oliva, T.A, and Smith, M.F., (2000) The role of Internet in Supply Chain Management, Industrial Marketing Management, Vol. 29 (-), pp: 45-46.

Lancioni, R, Schau, H. J., and Smith, M.F., (2002) Internet impacts on the supply chain management, Industrial Marketing Management, Vol. 32 (-), pp: 173-175.

Lee, H.L., and Wang, S., (2001), E-Business and Supply chain integration [online]. Stanford: Stanford University, Available from: http://www.sauder.ubc.ca/bcom/course_resources/comm442/docs/EbusandSCIntegratio n_HLee.pdf. [Accessed 3rd June 2006]

Lindstrom, M., (2001) Clicks, Bricks and Brands, London: Kogan Page 


\section{N Macrothink}

International Journal of Management Innovation Systems ISSN 1943-1384

2009, Vol. 1, No. 2: E4

Lindstrom, M., (2004), Branding is no longer child's play, Journal of consumer marketing, Vol. 21 (3), pp: 175-182.

Love, PE.D., Irani, Z., and Edwards, D.J., (2004), Industry-Centric benchmarking of information technology benefits, costs and risks for small-to medium sized enterprises in construction, Automation in Construction, Vol. 12 (-), pp: 507-524.

Love, P.E.D., Irani, Z., Standing, C., Lin, C., Burn M. J., (2005), The enigma of evaluation: benefits, costs and risks of IT in Australian small medium-sized enterprises, Information and Management, Vol. 42(7), pp: 947.

Luftman, J., and Brier, T., (1999), Achieving and Sustaining Business-IT Alignment, California Management Review, Vol. 42 (1), pp: 109-122.

Mahadevan, B., (2000), Business models for Internet-Based E-commerce: An Anatomy, California Management Review, Vol. 42 (4), pp: 55-69.

Mahajan, V., and Venkatesh, R., (2000), Marketing Modelling for e-business, International Journal of Research in Marketing, Vol. 17(-), pp: 215-225.

Merriless, B., and Fry, M.L., (2002), Corporate Branding: A framework for e-retailers, Corporate Reputation Review, Vol. 5 (2/3), pp: 213-225.

Morath, P., (2000), Success @ e-business, Berkshire: McGraw-Hill, 2000, pp: 13

Moscove S.A., (2001), E-Business Security and Controls. CPA Journal, Vol. 71(11), pp. 40-44.

Nasser, J., (2001) Fast ride, Executive Excellence, Vol. 18 (8), pp 5-6.

Oechsle, S.J., (2002), Brands and broadband- a communications opportunity, Corporate Reputation review, Vol. 5 (2/3), pp: 176-191.

Office of National Statistics, (2005) 2004 E-Commerce survey of business: Information and Communication Technologies adoption and usage, London: ONS.

Oppenheim, C., (1999), The legal and Regulatory Environment for Electronic Information, Third Edition, Gloucestershire: Infornotics

Pederson, L., (2002) E-Risk Management [online] Hamilton: Sedgwick Europe Risk services. Available from: http://www.gtnews.com/article/2262.cfm. [Accessed 20th October 2003]

Pennathur, A., (2001), "Clicks and bricks": e-Risk Management in the age of Internet, Journal of Banking and Finance, Vol. 25(11), pp 2103

Prestige, W.D., (2003), Supply management and e-procurement: creating value in the supply chain, Industrial Marketing Management, Vol. 32 (-), pp: 219-226.

Plummer, D.C., (1999), The faces of E-Business: Finding the right perspective, Stamford: Gartner Advisory group.

Poindexter, J.C., and Baumer, D., (2002), Cyberlaw and E-Commerce, New York: McGrawHill Irwin.

Poirier, C, C., (1999), Advanced Supply Chain Management, Washington D.C: Berrett-Koehler

Poirier, C, C., and Bauer, M.J., (2001), E-Supply Chain: Using the Internet to Revolutionize Your Business, Washington D.C: Berrett-Koehler

Porter, M.E., (2001), Strategy and the Internet, Harvard Business Review, Vol. 79 (2), pp: 63-78.

Ratnasingham, P., (1998), Internet- based EDI trust and security, Information Management \& Computer Security, Vol. 6(1), pp: 33-39.

Rayport, J.F., (1999), The Truth about Internet Business Models, Strategy and Business, Third Quarter. 
Rayport, J.F., and Jaworski, B.J., (2001), e-commerce, London: McGraw-Hill/Irwin, pp. 6-7.

Ribbink, D., Van Riel, A.C.R., Liljander, V., and Streukens, S., (2004), Comfort your online customer: quality, trust and loyalty on the Internet, Managing Service Quality, Vol. 14(6), pp: 446-456.

Rossi, M., (2002) Stand alone E-business insurance: Who is buying it, Who is selling it, and Why? [online]. Dallas: International Risk Management Institute. Available from http://www.irmi.com/Expert/Articles/2002/Rossi09.aspx [accessed on 25th November 2004]

Rotondaro, R.G., (2002), Defining the customer's expectations in e-business, Industrial management and Data systems, Vol. 102 (9), pp: 476-482.

Rowley, J., (2004a), Just another channel? Marketing communication in e-business, Marketing Intelligence \& Planning, Vol. 22 (1), pp: 24-36.

Rowley, J., (2004b), Online Branding, Online Information Review, Vol. 28 (2), pp: 131-141.

Rowley, J., (2004c), Online branding: the case of McDonald's, British Food Journal, Vol.106 (3), pp: 228-237.

Safran, S., and Franklin, T., (2002) E-Business and E-payments: How? Who? How much? [online]. Available from: http://www.bccresearch.com/comm/G263.html [accessed on $23^{\text {rd }}$ September 2005]

Schoder, D., and Ling Yin, P., (2000), Building firm trust online, Communications of the ACM, Vol. 43 (12), pp: 73-79.

Scott, J., (2004), Perceived dimensions of E-Business risks, Information Systems and ebusiness Management, Vol. (4), pp. 45-56.

Shankar, V., Rangaswamy, A., and Pusateri, M., (1999), The online medium and customer price sensitivity. [online] PA: Penn State University. Available from http:// http://e-commerce.mit.edu/papers/ERF/ERF45.pdf [Accessed on 5th June 2006]

Shapiro, C., and Varian H.R, (1999), Information Rules, Boston: Harvard Business School Press.

Simeon, R., (2001), Evaluating the branding potential of web sites across borders, Marketing Intelligence and Planning, Vol. 19 (6), pp: 418: 424.

Smith, D. (2000), E-Business Strategy Risk Management. Computer Law \& Security Report, Vol. 16 (6), pp. 394-396

Soliman, F, and Youssef, M., (2001), The impact of some recent developments in e-business on the management of next generation manufacturing, International Journal of Operations and Production Management, Vol. 21 (5/6), pp.538-564.

Solms, R. V., (1999), Information Security Management: Why standards are important, Information Management and Computer Security, Vol.7(1),pp:50-57.

Srinivasan, R., Lilien, G.L., and Rangaswamy, A., (2002), Technological Opportunism and Radical Technological Adoption: An application to E-Business, [online], PA: Penn State University, Available from: http://www.smeal.psu.edu/ebrc/publications/res_papers/2000_01.pdf. [ Accessed on 6th June 2006]

Tapscott, D., (1998), Blueprint to the digital economy; creating wealth in the era of e-business, New York: McGraw-Hill.

Timmers, P., (2000), Electronic Commerce, Chichester: John Wiley \& Sons

Upshaw, L.B., (2001), Building a brand.comm., Design Management Journal, Rowley, J., (2004), Just another channel? Marketing communication in e-business, Marketing Intelligence \& Planning, Vol. 22 (1), pp: 24-36. Vol. 12 (1), pp: 34-41 
Upton, N., (2001) Managing the Risks of e-Business [online]. London: Centre for the Network Economy, London Business School. Available from: http://forum.london.edu/lbsfacpubs.nsf/researchCentre/6C20616DFB31E0D180256A9 60003E0823/\$File/03\%20Managing\%20the\%Risks\%20Upton.doc [Accessed on $3^{\text {rd }}$ October 2005]

Venkatraman, N., (2000), Five Steps to a Dot.Com Strategy: How to find your footing on the web, Sloan Management Review, Vol. 15(3), pp: 15-29

Ward, M.R., and Lee, M.J., (2000), Internet shopping, consumer search and product branding, The Journal of Product and Brand Management, Vol. 9 (1), pp: 6-16.

Wen, J., (1998) Internet computer virus protection policy, Information management and computer security, Vol. 6 (2), pp: 66-71.

Willcocks, L., and Plant, R., (2001), Pathways to E-Business Leadership: Getting from Bricks to Clicks, MIT Sloan Management Review, Vol. 42 (3), pp: 50- 59.

Wilson, R.F, (2002), Planning your Internet Marketing Strategy; A Doctor Ebiz

guide, New York: John Wiley and Sons, 2002.

Wise, R., and Morrison, D., (2000), Beyond the Exchange: the future of B2B, Harvard Business Review, Vol. 78 (6), pp: 86-96.

Wong, H., and Merrilees, B., (2005), A brand orientation typology for SMEs: a case research approach, Journal of Product and Brand Management, Vol. 14(3), pp: 155-162.

Wu, F., Mahajan, V., and Balasubramanium, S., (2003), An Analysis of E-Business Adoption and its Impact on Business Performance, Journal of the Academy of Marketing Science, Vol. 31 (4), pp: 425-447.

Zettlemeyer, F., (2000), Expanding to the Internet: Pricing and communication strategies when firms compete on multiple channels, Journal of Marketing Research, Vol. 37 (3), pp: 292-308.

\footnotetext{
${ }^{i}$ For the purposes of this paper, E-Business is defined as the "The practice of performing and coordinating critical business processes such as designing products, obtaining supplies, manufacturing, selling, fulfilling orders, and providing services through the extensive use of computer and communication technologies and computerised data”. (Alter, 2002, p.6)

ii One of the earliest adopters of the term E-Business was IBM. Previously, E-Commerce was the word used to denote electronic exchange of information and its realisation.

iii According to Department of Trade and Industry (DTI) in UK, small businesses are defined as one with less than 50 employees, whereas the medium sized businesses are defined as one with less than 250 employees (DTI, 1999). European Union has also adopted the same definition but has also added monetary clauses in classifying small and medium sized business. Currently, business with less than 250 employees and less than 40 million euros in annual turnover are categorised as medium sized businesses
} 